
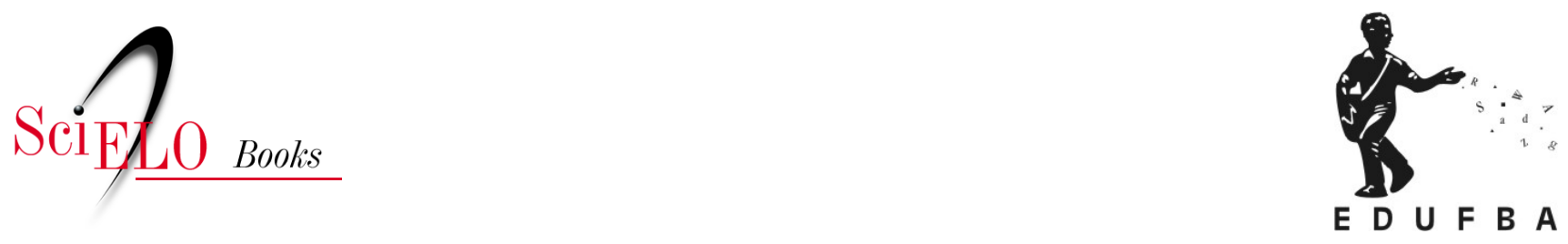

\title{
Reflexões \\ Meteoros, meteoritos e o nosso Bendegó
}

\author{
Nelson De Luca Pretto
}

PRETTO, N.D.L. Meteoros, meteoritos e o nosso Bendegó. In: Educações, culturas e hackers: escritos e reflexões [online]. Salvador: EDUFBA, 2017, pp. 140-142. ISBN: 978-85-232-2019-8.

https://doi.org/10.7476/9788523220198.0030.

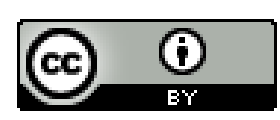

All the contents of this work, except where otherwise noted, is licensed under a Creative Commons Attribution $\underline{4.0 \text { International license. }}$

Todo o conteúdo deste trabalho, exceto quando houver ressalva, é publicado sob a licença Creative Commons Atribição 4.0. 


\section{Meteoros, meteoritos e o nosso Bendegó}

Nessa semana, passou pela beirada da Terra o asteroide 2012 DA14, somente a 27 mil quilômetros de distância. Em termos astronômicos, isso não é nada. No mesmo dia e numa coincidência absolutamente impactante (perdoe-me o trocadilho!), um meteoro de cerca de 7 mil toneladas e 45 metros de largura entrou na atmosfera em grande velocidade, desintegrou-se na atmosfera e espatifou-se no solo da região dos Montes Urais, na Rússia. O estrago foi grande e o mais curioso é que a sua chegada foi amplamente registrada por câmeras instaladas nos carros que circulavam pelas estradas e ruas da região. As imagens estão no Youtube e são impressionantes.

A pergunta que imediatamente tomou conta de rede foi o motivo de tantos carros terem câmeras filmando tudo que vinha pela frente - e pelos ares! - e, com isso, registrarem o fenômeno astronômico. Foi assim que ficamos sabendo que na Rússia, em função da corrupção (ahhhh!), muita gente se joga em frente de carros para, após o "acidente", abrir processo contra motoristas e, com isso, receber indenizações milionárias. Se isso é verdade ou não, pouco importa. O curioso é que, assim, pudemos acompanhar o fenômeno de forma nunca antes registrada na história da astronomia.

O fato é que o intruso meteoro literalmente ofuscou a passagem do 2012 DA14, que seria a grande estrela (oopps!) do dia, já que, como não tinha tamanho suficiente para ser visto a olho nu, teria a sua passagem registrada e transmitida ao vivo pela Nasa. De fato, isso aconteceu e as imagens circularam pela rede.

São muitos os interessados em observação astronômica, sejam profissionais ou amadores. Uma importante iniciativa levada a cabo pela Universidade de Berkeley, na Califórnia, é o projeto Seti@home que busca por inteligência extraterrestre (Search for Extraterrestrial Intelligence SETI), congregando voluntários do mundo inteiro que colocam à disposição do projeto seus computadores enquanto estão em modo descanso, 
construindo, pela rede e em processo de colaboração, um supercomputador para analisar os dados coletados por radiotelescópios. O projeto foi lançado originalmente em 1999, conta hoje com a participação de mais de 666 mil usuários e, com isso, tem contribuído muito para o desenvolvimento da área.

Voltando ao meteoro que caiu na Rússia, por conta dele, ao longo desse final de semana, foram publicadas inúmeras matérias sobre outros corpos celestes que caíram na Terra. Um dos relembrados aterrissou aqui na Bahia na época do Império ${ }^{31}$, perto de um riacho chamado Bendegó, em Monte Santo. Virou o nome do dito e trouxe misticismo para a região. Houve grande polêmica sobre o destino da pedra, que ficou por lá durante um bom tempo, até que foi considerada importante achado astronômico e, com isso, levada para a Quinta da Boa Vista, no Rio de Janeiro.

Lá em Monte Santo, foi construído um monumento ao tal pedregulho, monumento esse depois destruído pela população. Achei na Wikipedia um cordel que conta um pouco sobre essa polêmica:

A pedra constituída

De ferro, níquel e encanto.

Até o dia de hoje

Provoca tristeza e encanto

Queremos nossa pedra de volta

De volta pro nosso canto.

\footnotetext{
${ }^{31}$ O leitor André Rosa, no site do Terra Magazine, fez uma importante observação sobre essa minha informação, que aqui incorporo, com gratidão: “... vale dizer que o Bendegó não caiu na Bahia na época do império. É estimado que a queda do Bendegó tenha ocorrido há milhares de anos. O que ocorre é que ele foi identificado ainda na época da colônia, e desde aquela época, foram realizadas tentativas de levá-lo, primeiro à Salvador, depois à capital da colônia. Durante o século 18 e 19, inúmeras tentativas falharam. O Bendegó só foi levado para o Rio de Janeiro na época em 1888, depois de uma complicada operação que envolveu centenas de trabalhadores, um planejamento de engenharia e logística que quase culminou em tragédia. O Bendegó se encontra, hoje, no Museu Nacional, na Quinta da Boa Vista. Deve ser dito que existe um movimento na região de Canudos, intitulado 'volta bendegó', que está relacionado à crença de que as secas que acometem a região estejam ligadas à retirada do meteoro do local original de sua queda".
} 
Além do cordel, muita música foi criada a partir do meteorito. Relembro, com muito carinho, do grupo baiano de mesmo nome liderado por Gereba, composto, entre outros, pelo mago do atual marketing político petista, João Santana Filho que, à época, era somente Patinhas, meu contemporâneo do Colégio Antônio Vieira, em Salvador.

Tenho um dos belos discos (LP) desse grupo, criado na década de 1970 do século passado. Procurei um pouco sobre eles na internet e, por conta disso, encontrei o projeto do Dicionário Cravo Alvin da Música Popular Brasileira ${ }^{32}$ que tem apoio da FIPEP e Faperj. Nele, um pouco da história do grupo. As composições do Bendegó eram de Gereba e Patinhas, mas também estavam presentes grandes nomes da música baiana como Zeca, Kapenga, Carlos Eládio, Tuzé de Abreu, Carlos Pita, Capinam e muitos outros. Bela é As muié santa de Canudos, composição de Gereba e Patinhas, mas no Youtube só achei Além de Arembepe, com uma divertida imagem da turma.

Ouça a música, assista aos vídeos e se prepare: outros meteoros e meteoritos virão e o mundo, por certo, não vai acabar por conta deles. Mas muita arte e ciência poderão ser produzidas.

\section{Um parque genial com skate, livros e games}

Dias atrás, estive em Passo Fundo, no Rio Grande do Sul. Cidade bem arrumada, com boa comida e um polo universitário que cresce a olhos

\footnotetext{
${ }^{32}<$ http://www.dicionariompb.com.br/bendego/dados-artisticos>. Acesso em: 10 maio 2017.
} 